\title{
ANALISIS KONSENTRASI CO DI JALAN TERHADAP PENGARUH JUMLAH KENDARAAN DAN BAKU MUTU UDARA AMBIEN
}

\author{
Latifa Andjani
}

\author{
Jurusan Teknik Lingkungan, Fakultas Arsitektur Lanskap dan Teknologi Lingkungan, \\ Universitas Trisakti, Jakarta, Indonesia
}

Email korespondensi: latifa08214038@std.trisakti.ac.id

\begin{abstract}
ABSTRAK
Kendaraan bermotor sekarang menjadi salah satu kebutuhan utama masyarakat perkotaan di Indonesia. Situasi ini tentu mempengaruhi jumlah kendaraan bermotor yang terus meningkat. Gas buangan yang dipancarkan oleh kendaraan bermotor mengandung polutan udara dengan persentase CO tertinggi $70,5 \%$. Presentase partikulatnya kecil tetapi polutan ini memiliki dampak berbahaya pada kesehatan pernapasan dibandingkan dengan polutan lainnya. Tujuan dari penulisan karya ilmiah ini adalah untuk menganalisis konsentrasi CO terhadap jumlah kendaraan bermotor di Jalan dan membandingkan hasil pengambilan sampel dengan standar kualitas udara ambien PP No. 41 tahun 1999. Metode yang digunakan pada pengukuran CO adalah sampling roadside udara ambien CO untuk setiap fungsi ruas jalan. Secara umum, konsentrasi CO yang berasal dari kendaraan motor tidak melebihi baku mutu udara ambien.
\end{abstract}

Kata Kunci: Karbon Monoksida (CO);Kendaraan Bermotor; Baku mutu udara ambien;

\section{PENDAHULUAN}

Pesatnya kemajuan ekonomi di kota-kota besar Indonesia seperti Jakarta mendorong peningkatan aktivitas masyarakat hingga bertambahnya kebutuhan transportasi seperti kendaraan pribadi. Kendaraan pribadi sangat menguntungkan bagi masyarakat terutama untuk mobilitas dan dalam menghemat waktu. Angka kepemilikan kendaraan bermotor di Jakarta menunjukkan cenderung terus meningkat. Berdasarkan hasil inventarisasi Siami (2014) emisi dari sektor tranportasi pada segmen jalan di DKI Jakarta, beban emisi polutan CO sebesar 973734,26 ton/tahun. Pertumbuhan jumlah kendaraan ini tidak sebanding dengan perkembangan jalan di DKI Jakarta yang hanya $0.01 \%$ setiap tahun (Tribun News, 2014). Akibatnya, peningkatan kendaraan dapat menimbulkan kemacetan lalu lintas. Pola dari kepadatan kendaraan bermotor terutama terjadi pada pagi hari ketika masyarakat berangkat ke tempat kerja dan sore hari ketika masyarakat pulang kerja. Hal ini dapat menimbulkan permasalahan yang serius seperti semakin tingginya tingkat pencemaran udara yang diakibatkan oleh emisi gas buang yang dihasilkan.

Polutan CO yang dikeluarkan oleh kendaraan bermotor memberi dampak negatif bagi kesehatan manusia. Senyawa dalam polutan $\mathrm{CO}$ dapat mengikat hemoglobin $(\mathrm{Hb})$ yang berfungsi mengantarkan oksigen segar ke seluruh tubuh, yang menyebabkan terganggunya fungsi $\mathrm{Hb}$ untuk membawa oksigen ke seluruh tubuh (carboxyhaemoglobin). Berkurangnya persediaan oksigen ke seluruh tubuh akan membuat sesak napas dan dapat menyebabkan kematian dalam jangka waktu yang lama.

Peraturan Pemerintah No. 41 tahun 1999 tentang pengendalian pencemaran, telah mengatur baku mutu rata-rata harian untuk $\mathrm{CO}$ adalah $65 \mu \mathrm{g} / \mathrm{m}^{3}$. Berdasarkan uraian diatas maka penulisan karya imliah ini disusun dengan tujuan menganalisis konsentrasi CO kendaraan bermotor pada jalan dengan baku mutu udara ambien yang berasal dari kendaraan bermotor. 


\section{TINJAUAN PUSTAKA}

Definisi pencemaran udara berdasarkan Peraturan Pemerintah No. 41 tahun 1999 tentang pengendalian pencemaran udara, adalah masuknya atau dimasukkannya zat, energi, dan/atau komponen lain ke dalam udara ambien oleh kegiatan manusia, sehingga mutu udara ambien turun sampai ke tingkat tertentu yang menyebabkan udara ambien tidak dapat memenuhi fungsinya.

Karbon monoksida (CO) adalah gas yang tak berwarna, tak berbau, dan tak berasa. Gas CO merupakan gas yang sangat stabil dan memiliki waktu tinggal di atmosfer sekitar 2-4 bulan. Gas CO dihasilkan dari proses pembakaran tidak smepurna bahan bakar fosil, seperti bensin, minyak dan kayu bakar. Sifat Fisik dari Karbon Monoksida (CO) adalah :
1. Fasa
: Gas tak berbau, tak berwarna

2. Masa molar

: $28,0101 \mathrm{~g} / \mathrm{mol}$

3. Titik leleh $\quad:-205^{\circ} \mathrm{C}(68 \mathrm{~K})$

4. Titik didih $\quad:-192{ }^{\circ} \mathrm{C}(81 \mathrm{~K})$

5. Kelarutan dalam air : $0,0026 \mathrm{~g} / 100 \mathrm{~mL}\left(20^{\circ} \mathrm{C}\right)$

Di daerah perkotaan dengan lalu lintas yang padat konsentrasi gas $\mathrm{CO}$ berkisar antara 10-15 ppm. CO yang dihirup mudah diserap oleh paru-paru dan mengalir dalam aliran darah, menghasilkan ikatan antara oksigen dan hemoglobin dalam sel darah merah, membentuk karboksihemoglobin dan oksihemoglobin (Jason, 2017). Kendaraan bermotor menurut Peraturan Pemerintah RI No.55 Tahun 2012 tentang Kendaraan, adalah setiap kendaraan yang digerakkan oleh peralatan mekanik berupa mesin selain kendaraan yang berjalan di atas rel. Jenis kendaraan bermotor menurut Peraturan Pemerintah Nomor 55 Tahun 2012, yaitu sepeda motor, mobil penumpang, bus, mobil barang ,dan kendaraan.

\section{Pengertian Emisi}

Menurut PP No. 41 tahun 1999 tentang Pengendalian Pencemaran Udara yang dimaksud dengan emisi adalah zat, energi dan/atau komponen lain yang dihasilkan dari suatu kegiatan yang masuk dan/atau dimasukkannya ke dalam udara ambien yang mempunyai dan/atau tidak mempunyai potensi sebagai unsur pencemar. Pembakaran tidak sempurna dari kendaraan bermotor menyumbang sebagian emisi CO. Karbon monoksida terbentuk apabila terdapat kekurangan oksigen dalam proses pembakaran.

Tabel 1. Hasil Penelitian

\begin{tabular}{|c|c|c|}
\hline Judul Paper, tahun & Penulis & Hasil Penelitian \\
\hline $\begin{array}{l}\text { Analisis Dampak Kualitas } \\
\text { Udara Karbon Monoksida } \\
\text { (CO) Di Sekitar Jl. } \\
\text { Pemuda Akibat Kegiatan } \\
\text { Car Free Day } \\
\text { Menggunakan Program } \\
\text { Caline4 dan Surfer Studi } \\
\text { Kasus: Kota Semarang, } \\
2017\end{array}$ & $\begin{array}{l}\text { DikenYus Damara, Irawan } \\
\text { Wisnu Wardhana, Endro } \\
\text { Sutrisno }\end{array}$ & $\begin{array}{l}\text { - } \text { Konsentrasi CO pada Jl. MH Thamrin } \\
\text { saat Car Free Day masih memenuhi } \\
\text { standar baku mutu PP } 41 \text { Tahun } 1999 \\
\text { sebesar } 6920,7910 \mu \mathrm{g} / \mathrm{NM}^{3} \\
\text { Dapat dilihat dari grafik untuk nilai } \\
\text { sig hubungan antar konsentrasi CO } \\
\text { dengan beban emisi kendaraan bermotor } \\
\text { sebesar 0,0819, kecepatan angin sebesar } \\
\text { 0,2654, dan temperatur sebesar 0,7625, } \\
\text { nilai sig dari ketiga grafik tersebut } \\
\text { berada pada nilai > 5\% atau lebih besar } \\
\text { dari 0,05 yang artinya adanya hubungan } \\
\text { linier dengan konsentrasi CO. }\end{array}$ \\
\hline
\end{tabular}




\begin{tabular}{|c|c|c|c|}
\hline Judul Paper, tahun & Penulis & & Hasil Penelitian \\
\hline $\begin{array}{l}\text { Pengaruh Jumlah } \\
\text { Kendaraan Dan Faktor } \\
\text { Meteorologi Terhadap } \\
\text { Konsentrasi Karbon } \\
\text { Monoksida (CO) Di Jalan } \\
\text { Pandanaran } \\
\text { Kawasan Simpang Lima, } \\
\text { Kota Semarang, 2012 }\end{array}$ & \begin{tabular}{l}
\multicolumn{3}{l}{ Sartikasmawaty } \\
Sudarno, Dwi \\
Handayani
\end{tabular} & $\begin{array}{r}\text { Sinaga, } \\
\text { Siwi }\end{array}$ & $\begin{array}{l}\text { Rata-rata harian pada hari Senin, Selasa, } \\
\text { dan Rabu sebesar } 15 \mathrm{ppm} \text { atau sebesar } \\
17.177 \mu \mathrm{g} / \mathrm{NM}^{3} \\
\text { - Pengukuran, jumlah kendaraan } \\
\text { berbanding lurus dengan jumlah } \\
\text { konsentrasi CO. Semakin tinggi jumlah } \\
\text { kendaraan maka konsentrasi CO juga } \\
\text { semakin meningkat. }\end{array}$ \\
\hline $\begin{array}{l}\text { Perhitungan Penurunan } \\
\text { Beban Emisi Pencemaran } \\
\text { Udara Dari Pembangunan } \\
\text { Jalur Tol Jorr W2 Di DKI } \\
\text { Jakarta, } 2014\end{array}$ & $\begin{array}{l}\text { Lailatus Siami, } \\
\text { Sofyan dan Russ } \\
\text { Frazila }\end{array}$ & $\begin{array}{l}\text { Asep } \\
\text { Bona }\end{array}$ & $\begin{array}{l}\text { - Beban emisi tertinggi adalah CO } \\
\text { sebanyak } 70,68 \% \text { dari total semua jenis } \\
\text { polutan. } \\
\text { Emisi CO tertinggi berada pada jalan } \\
\text { utama, hal ini disebabkan jumlah } \\
\text { kendaraan berjenis sepeda motor yang } \\
\text { menjadi kontributor utama emisi CO di } \\
\text { jalan utama. }\end{array}$ \\
\hline
\end{tabular}

\section{Metode dan analisis}

Pengukuran polutan pencemar CO disesuaikan dengan SNI 19-7119.9-2005 berkaitan dengan Penentuan Lokasi Pengambilan sampel pada jalan (roadside). Data primer meliputi pengukuran polutan $\mathrm{CO}$ dengan pengukuran jumlah kendaraan masin-masing jenis menggunakan hand counter. Menurut (Augustine, 2017 pengambilan pengukuran polutan didapat melalui metode sampling-analisis (aktif, pasif maupun real-time) pada periode waktu tertentu. Berdasarkan Peraturan Menteri Lingkungan Hidup Nomor 12 Tahun 2010 tentang Implementasi Pengendalian Pencemaran Udara di perkotaan, pemantauan kualitas udara dapat dilakukan dengan interval pagi, siang, sore dan malam. Waktu pengukuran juga dapat dilakukan dengan memperhatikan jam padat (peak hour) pada lokasi pengukuran (Bachtiar, 2017). Data konsentrasi CO didapat pada jalan dirata-ratakan menjadi konsentrasi per periode waktu pagi, siang, sore dan malam (jam). Sebagai contoh pengukuran dapat dilakukan pada interval waktu sebagai berikut (Irawan, 2016) :
a) Jam Pagi : :06.00-08.00
b) Jam Siang : : $11.00-13.00$
c) Jam Sore $: 16.00-18.00$
d) Jam Malam : $: 19.00-21.00$

\section{PENUTUP}

Berdasarkan 3 data penulisan dapat disimpulkan bahwa jumlah kendaraan berpengaruh dan berbanding lurus terhadap konsentrasi CO. Konsentrasi CO pada jalan secara umum tidak melebihi ambang batas standar kualitas udara ambien pada PP 41 Tahun 1999. Jenis kendaraan yang menghasilkan emisi tertinggi adalah sepeda motor. Dari penulisan studi pustaka, diperlukan penelitian lebih lanjut untuk mempermudah pengendalian terhadap kualitas udara ambien perkotaan.

\section{DAFTAR PUSTAKA}

Intan Augustine, Hernani Yulinawati, Endro Suswantoro. 2017. Application Of Open Air Model (R Package) To Analyze Air Pollution Data. Indonesian Journal of Urban and Environmental Technology. Vol. 1, No. 1, page $94-109$.

DOI: http://dx.doi.org/10.25105/urbanenvirotech.v1i1 
Diken Yus Damara, Irawan Wisnu Wardhana, Endro Sutrisno. 2017. Analisis Dampak Kualitas Udara Karbon Monoksida (CO) Di Sekitar Jl. Pemuda Akibat Kegiatan Car Free Day Menggunakan Program Caline4 dan Surfer Studi Kasus: Kota Semarang, E-Journal S1 Undip. Vol. 6, No.1.

http://ejournal-S1.undip.ac.id./index.php/tlingkungan

Dinas Perhubungan (Dishub) . 2015. Laporan Jumlah Kendaraan tahunan. Jakarta

Jason J. Rose, Ling Wang, Qinzi Xu. 2017. Carbon Monoxide Poisoning: Pathogenesis, Management, and Future Directions of Therapy. ATS Journal. Vol. 195, No. 5

DOI : https://doi.org/10.1164/rccm.201606-1275CI

Karliansyah. 2018. Perbandingan Kadar Karbon Monoksida (CO) di Udara Ambien berdasarkan Keberadaan Pohon Angsana (Pterocarpus Indicus) di beberapa Jalan Raya. Medan: Fakultas Kesehatan Masyarakat Universitas Sumatera Utara.

Lailatus Siami, Asep Sofyan dan Russ Bona Frazila. 2014. Perhitungan Penurunan Beban Emisi Pencemaran Udara Dari Pembangunan Jalur Tol Jorr W2 Di DKI Jakarta. Jurnal Teknik Lingkungan Institut Teknologi Bandung. Vol. 20, No.2, (Hal 152161)

DOI: http://dx.doi.org/10.5614\%2Fjtl.2014.20.2.6

Pemerintah Republik Indonesia. 1999. Peraturan Pemerintah Republik Indonesia Nomor 41 Tahun 1999 Tentang Pengendalian Pencemaran Udara. Jakarta : Pemerintah Republik Indonesia.

Sartikasmawaty Sinaga, Sudarno, Dwi Siwi Handayani. 2012. Pengaruh Jumlah Kendaraan Dan Faktor Meteorologi Terhadap Konsentrasi Karbon Monoksida (CO) Di Jalan Pandanaran Kawasan Simpang Lima, Kota Semarang. E-Journal S1 Undip. Vol. 3, No.1.

SNI 19-7119.9-2005. 2005. Udara Ambien - Bagian 9: Penentuan Lokasi Pengambilan Contoh Uji Pemantauan Kualitas Udara Roadside. Indonesia: BSN.

Vera Surtia Bachtiar, Vivin Alfirna. 2017. Studi Konsentrasi CO Akibat Kendaraan Bermotor Di Kawasan Pasar Tradisional Kota Padang. Jurnal Teknik Lingkungan Universitas Andalas Dampak. Vol 14, No 2.

DOI: https://doi.org/10.25077/dampak.14.2.113-121.2017 